\title{
Expert Teacher: Objective Determinants of Developing and Maintaining Expertise (in FLT Perspective)
}

\author{
Klara Ulicna - Michaela Pisova - Svetlana Hanusova - \\ Vera Janikova - Petr Najvar
}

\section{DOI: 10.18355/XL.2016.09.01.91-109}

\begin{abstract}
The study focuses on foreign language teachers' immediate and broader environment and its influence on their professional development towards expertise from their own perspectives. The study was conducted within a research project dealing with the nature of expertise of foreign language teachers. Its last, third, phase, which we are to present in this study was diachronically oriented and aimed to explore the determinants of the development of foreign language teachers' expertise. The data were collected in biographic interviews with 8 teachers at Czech lower secondary schools. Content analyses of verbal protocols based on theory-driven system of categories was used bringing some interesting results.
\end{abstract}

Key words

teacher expertise, foreign language teacher, professional development, objective determinants, biographic interview

\section{Introduction}

Outstanding performances in various domains of human endeavor have always attracted attention. Serious scientific attempts to capture the nature of expertise, however, began only in the last century, and the last four or five decades have witnessed a dynamic development in research into expertise, primarily in order to explain the prerequisites for expert performance (Ericsson, 2006).

Research in teacher expertise was launched in the 1980s. In addition to its empirical and theoretical goals, study of expertise in teaching aims to raise the status of teachers by demonstrating that like experts in other professions, expert teachers possess knowledge and skills which are equally sophisticated. Research on expertise, its identification, development and assessment also helps to set the horizons towards which the members of the profession may aspire (Tsui, 2005: 184-185). Last but not least, learning about expertise and its acquisition may provide information critical for reshaping and transforming initial as well as in-service teacher education.

Building on the perception of expertise as a dynamic and unstable phenomenon set within a particular time and context (Glaser, Chi, 1988), attention must also be paid to the examination of the factors that determine its development and maintenance. This study focuses on teacher immediate and broader environment and its influence on teacher professional development towards expertise from their own perspectives, i.e. on expert teachers' subjective perceptions of external or objective determinants of their professional growth.

With regard to the above characteristics of expertise as a situated phenomenon, the study needs to be contextualized in two aspects: the specifics of the teachers' subject subculture - foreign language teaching (FLT), and the specifics of the broader cultural framework within which the expert teachers under investigation operate, i.e. the social and political environment of the Czech Republic and its influence on foreign language teaching.

Both research and policy all over the world have treated teaching as a generic activity. However, it is gradually more and more obvious that the view of content as context (Grossman, Stodolsky, 1995) is a perspective that should be reflected. 
Representatives of various school subjects possess different features, histories and statuses that affect teachers' work, and their shared beliefs and norms can usefully be characterized as a subject subculture (Ball, Lacey, 1984). Grossman and Stodolsky (1995) emphasize the following differences among school subjects: degree and status within the school; scope and coherence of the curriculum; perceived or inherent sequentiality of the subject and curriculum. Research studies brought abundance of findings which examine different perspectives of the topic in question, e.g. Siskin (1994) discovered that English (as a mother tongue) and math departments at different schools share more common features than these at the same school; Ball (1981) claimed that math and foreign language teachers are most resistant to change, and numerous other studies might be mentioned.

What is, thus, the subculture of foreign language teachers specific in? In the course of time, foreign language teaching was perceived in different ways, specifically in relation to the state of the art of relevant scientific disciplines, social development and social demands put on language education. Larsen-Freeman and Freeman (2008: 150) claim that language as a subject, arguably more than any other content area, is constantly being redefined. [...] This may be because language teaching, unlike mathematics or history, has not had a consistent disciplinary home in which to anchor its content or theories of learning, teaching, and knowing, or mastery.

Moreover, compared to other school subjects, the fact that foreign language communicative competence stands both as the aim and as the procedural means of education makes it unique, and puts specific demands on a teachers' pedagogical content knowledge (Wipperfürth, 2009). Next, interculturality and multilingualism/plurilingualism together with other cultural and social aspects of foreign language teaching have to be taken into consideration as the core cognitive and conative specifics of foreign language teachers (Lazar, 2003).

Foreign language teaching is a strongly ideologically bound area of school instruction, in comparison to other school subjects, such as math. Therefore, the study reflects the social and political context of eastern European countries and the sociopolitical turn from the communist to the post-communist era this area witnessed in the past 25 years. The presented research was conducted in the Czech Republic, where the change in a political regime had a great impact on foreign language teaching as well as its teacher education. The Czech context is also specific by the shift from a centralized to a decentralized curriculum during the first decade of the $20^{\text {th }}$ century, when curricular reform was implemented at all levels of education.

The study thus attempts to contribute to the current state of the art within the teacher expertise research through a culturally rooted insight into the phenomenon. We believe that acknowledging and exploring different cultural perspectives of the phenomenon in question may enable us to compare, but, more importantly, to search for the common features across the cultural boarders.

\section{Rationale}

Back in 1986 Berliner in his presidential address for the American Educational Re-search Association called for more attention to the study of expert teachers and their performance. In spite of advances both in the study of expertise as a generic phenomenon (Glaser, Chi, 1988; Hatano, Inagaki, 1986; Boshuizen, Bromme, Gruber, 2004; Bransford, Brown, Cocking, 2005; Chi, 2011; Ericsson et al., 2006, etc.) and of teacher expertise specifically (Clark, Peterson, 1986; Brophy, Good, 1986; Bereiter, Scardamalia, 1993; Sternberg, Horvath, 1995; Tsui, 2003; Seidel, Shavelson, 2007; Hattie, 2003, 2012; Scheerens et al., 2010, etc.), Berliner's plea is still valid today.

Amongst the array of issues to be further pursued in expertise research, this study reflects the interest in finding out why some experienced teachers act as experts, 
while some do not, remaining, as Bereiter and Scardamalia (1993) noted, experienced non-experts. Thus, expertise is viewed as a dynamic phenomenon, as a lifelong process. The study acknowledges the social dimension of expertise. Social theory stresses the importance of context in the processes of becoming an expert: professional development towards expertise includes enculturation into professional culture (Boshuizen, Bromme, Gruber, 2004: 6). Since the 1990s approaches to teacher expertise research have been discussed in relation to the changes of both the immediate environment of educational institutions and classrooms and the broader social context.

For the purpose of our study, professional expertise is perceived in relation to the specific qualities of an individual and the accumulated collective qualities of a particular profession. In accord with Ericsson (2006: 3-4), an expert is defined as "someone widely recognized as a reliable source of knowledge, technique, or skill whose judgment is accorded authority and status by the public or his or her peers. Experts have prolonged or intense experience through practice and education in a particular field." The study focuses on expert teachers' professional lives and aims to capture the factors that determine the development of expertise and its maintenance.

\subsection{Determinants of expertise development in teaching}

In examining the determinants of the development of expertise in foreign language teachers, the study drew on research by Huberman (1993a) and Kelchtermans and Vandernberghe (1996), which identified material, organizational, social and cultural (cultural-ideological) factors and personal influences. The material, organizational and social factors were viewed as relating to the school context of, i.e. equipment, economic background, position and role of a teacher within the school, and social relations (relations with colleagues, school management, but also with parents). Cultural or cultural-ideological and personal factors were associated with teachers' values, norms and ideals.

Similarly, Richardson and Placier (2001) in their review brought together two main trends in teacher research - a focus on the individual or small groups and their cognitive, emotional and behavioral transformation, and an examination of changes in teachers from the institutional perspective, i.e. the influence of structural, cultural and political aspects of schools' operation on transformation of teachers and teaching.

Further on, Day and Gu (2010: 51-52) analyzed phases of a teachers' lives comparing and contrasting the nature of contexts which acted as influences and "critical incidents". The four categories they identified included: personal category (the life of teachers outside school, family support, social relations, health); pupils (pupils' level, attitude and motivation, behavior, teacher-pupil relationship); working environment (teachers' workplace, support from school management and colleagues, teachers' other roles and duties, promotion, workload, opportunities for professional development, etc.); politics (political agenda, e.g. educational policies, government initiatives and changes).

Obviously, the variables identified in the studies as determinants of teacher professional development may be roughly divided into two groups: the personality and individual characteristics of teachers, and the contextual and environmental issues. In this study we chose to adopt for them Pařizek's terminology (1994: 61-67), i.e. the distinction of the subjective and objective determinants of foreign language teachers' professional development and their paths to reaching and maintaining expertise. Further on in this study the focus will only be on the objective determinants.

\subsection{Objective determinants of teachers' professional development}

As regards objective determinants of expertise development, Pollard's (1982) conceptual model of three levels of social contextualization was found helpful in 93 
structuring the discussion. Pollard distinguished the interactive level of influence (pupils and their social groups - classes), the institutional level of influence (culture of the school, colleagues and school management), and the cultural level of influence (the local social community and the broader economic, political and cultural environment). The model considers teachers's actions to be creative responses to the constraints and opportunities posed by their context. As the secondary analysis of data from the international comparative study TALIS targeted at teacher professional development (Scheerens et al., 2010: 32-35) indicated a heightening accent on community learning and schools as learning communities in the last decade, this study will focus only on the institutional and cultural levels of influence.

At the level of institutional influence the centre of attention has been on the occupational and school culture as psycho-social conditions for teachers' actions. According to Deal and Peterson (1998: 28), "culture is the underground stream of norms, values beliefs, traditions and rituals that has built up over time as people work together, solve problems and confront challenges" (similarly Fullan, 2007, and others).

Among the high impact factors, the key one is usually referred to as school hierarchy, more specifically the style of leadership and the management structure. Current trends in educational management theory and research consider transformational leadership (Geijsel, Sleegers et al., 2003; Pol et al., 2013, for the Czech context) to be most effective in terms of professional learning support, namely clear formulation of the vision of the school, provision of individual support and intellectual stimulation. Further on, teacher involvement in the decision-making processes and provision of sufficient access to information increase their motivation and openness to change.

Undoubtedly, staff relationships represent another key factor. Hargreaves (2000) usefully analyzed the changes of accents in this area from Lortie's times (1975), when teacher isolation prevailed as expressed through the image of teacher as an independent artisan (Huberman, 1983b), to extremely strong collaborative rhetorics and practices (cf. Little, McLaughlin, 1993; Lieberman, Miller, 2000). Collegial relationships and teacher collaboration remain a major theme up till now, they are considered fundamental for expertise development in the light of the view of professional learning as a socially rooted process (Darling-Hammond, Richardson, 2009).

For current (as well as historical) role of the teacher, a significant degree of autonomy is both self-evident and essential. Clement and Vandenberghe (2000: 91) noticed that in order to collaborate in an effective way, teachers also need an autonomous phase of their actions. Mutual relationship between collegiality and autonomy, however, may cause polarized tension, which might hamper professional development towards expertise in individuals.

To conclude a brief discussion of the institutional level of influence, it should be noted that many educationalists (Richardson, Placier, 2001; Scheerens et al. 2010: 35) call for more systematic research into factors functioning within this level, into mutual interaction of psychological factors, leadership and organizational issues from various theoretical perspectives.

The cultural level of influence is, in Pollard's (1982) view, filtered through the institutional level for individual teachers. It encompasses broader social, political and economic factors that determine teacher professional development. Globally as well as locally (i.e. in the Czech Republic) current most frequently brought up issues include social changes and their consequences. Amongst them, increased demands on teacher and school responsibility and extension of tasks and requirements on schools are typically identified as the crucial ones (Terhart, 2005; Hargreaves, 2000). These 
requirements go hand in hand with often critical attitude of parents towards school and further reduction in the social prestige and status of teaching, which puts teachers on the defensive (Scherff, 2008). In conjunction with the effects of neo-liberal trends in education, teachers are often put under almost unbearable pressure, which might significantly affect their further professional development.

\section{Empirical study: objective determinants of expertise development in foreign language teachers in the Czech Republic \\ 2.1 Research context}

Research into objective determinants of expertise development and maintenance in a subculture of foreign language teachers was conducted within the framework of a complex research project Expert Teacher: the nature of expertise and determinants of professional development (in the foreign language teaching perspective). Over three years in the period from 2011 to 2013 the research team consisting of 5 researchers worked with 30 outstanding teachers of English and German as foreign languages, who taught at lower-secondary schools in the Czech Republic. They were initially recruited on the basis of social nominations, length of experience and professional qualifications. The research was conceived as a multiple case-study and was carried out in three phases. In the first and second phases of the research we looked at the expertise of teachers from a synchronous perspective: we focused on their performance, insight and knowledge. Next, we used the method of stimulated recall to capture the teachers' lived experience and interactive cognition. In the third phase the expertise of foreign language teachers was viewed diachronically, i.e. in terms of professional development of a particular teacher.

The study presents partial results of the analysis of data from the last phase, in which the aim was to analyze the factors that determined the processes of expertise development and maintenance, namely results in the area of objective determinants.

\subsection{Research methodology}

The main research question for this study was: What are the objective determinants of achieving and maintaining expertise in foreign-language teachers?

The research sample consisted 8 expert teachers $\left(\mathrm{n}_{\mathrm{f}}=6, \mathrm{n}_{\mathrm{m}}=2 ; \mathrm{n}_{\mathrm{E}}=6, \mathrm{n}_{\mathrm{G}}=2\right)$ selected through a detailed scrutiny in the first two phases of the multiple case study as the best representatives of expertise in foreign language teaching (Author 1 et al., 2013).

Regarding the research aims, the study was designed as a biographical research (Miller, 2000). The data collection instrument was an in-depth biographical interview (duration 30-45 $\mathrm{min}$ ). An essential precondition for biographical research, i.e. the advantage of mutual trust between the researcher and the respondent, was met, since trust had been established in the previous research phases.

Prior to data collection, respondents were asked to think about "the chapters in the book of [their] professional life". During the procedure, the researchers did not interfere in respondents' narrations and interjected probes only when necessary. Teachers were instructed in accord with McAdams (2007: unpaged):

Please begin by thinking about your life as if it were a book or novel.

Imagine that the book has a table of contents containing the titles of the main chapters in the story. To begin here, please describe very briefly what the main chapters in the book might be. Please give each chapter a title, tell me just a little bit about what each chapter is about, and say a word or two about how we get from one chapter to the next. As a storyteller here, what you want to do is to give me an overall plot summary of your story, going chapter by chapter. You may have as many 
chapters as you want, but I would suggest having between about two and seven of them.

With the consent of the respondent the interviews were audio recorded and transcribed. The transcripts were then subjected to qualitative content analysis. In the data analysis a neo-positivist biography was applied (Miller, 2000: 96-98) which accentuates a realistic view of respondent per se, but - unlike a realistic biography is based on deduction.

For the purpose of the content analysis a theory-driven system of categories was designed and piloted, with an idea unit as the unit of analysis. Direct correlation between four coders reached $76.5 \%$, inter-coder reliability was satisfactory (Cohen's kappa 0.711 , Krippendorff's alpha 0.71).

Alongside the methods described to ensure the reliability of the research, the criteria of trustworthiness and especially authenticity were observed (Toma, 2005: 405-424). In terms of authenticity, care was taken to maintain fairness, i.e. the voice of the respondent was preserved (in balance with the voice of the researcher), as well as ontological, educative authenticity in the sense of increasing the awareness of both partners. These criteria were also verified by the respondents who participated in the communicative validation phase thus contributing to a deeper insight into the biographies through a dialogic written form (by e-mail). Communicative validation adds value to the rigor of interview data analysis and also allows for further research insights (Lindlof, Taylor, 2002).

This is in accord with Ojemark's (2006: 4) conception of biographical research, its truthfulness and the role of respondents' self-perception and researchers' influence: "Biographies are a conscious reconstitution of history. We should not be seeking the truth, but rather to glean from the respondent's own interpretation of their life and the events within it what the truth is".

\subsection{Discussion of research results}

The system of categories for analysis is presented in Table 1 below. It also includes information about the number of respondents whose comments were found in each of the categories, and also total frequency of occurrence of statements in individual categories differed.

Tab. 1 Analysis: system of categories and frequency of occurrence

\begin{tabular}{|l|c|c|}
\hline OBJECTIVE DETERMINANTS: categories & $\begin{array}{l}\text { No. of } \\
\text { teachers }\end{array}$ & $\begin{array}{l}\text { No. of } \\
\text { statement } \\
\text { s }\end{array}$ \\
\hline Teacher education & 8 & 63 \\
\hline School culture & 8 & 28 \\
\hline School leadership & 4 & 13 \\
\hline Autonomy & 6 & 24 \\
\hline Colleagues / significant others & 8 & 66 \\
\hline Teacher appraisal / recognition by the community & 7 & 20 \\
\hline Parents (and community around school) & 5 & 14 \\
\hline Educational policy & 7 & 16 \\
\hline Economic conditions & 3 & 3 \\
\hline
\end{tabular}

Table 1 shows that in their narratives the teachers most frequently commented on their cooperation with colleagues, education and the school culture. If any conclusions may be made concerning the perceived importance of objective determinants, it can be concluded on the basis of the frequency of occurrence of the statements, that these played the most significant role on the paths towards expertise. On the other hand, the 
role of economic conditions in expert teachers' professional development seems to be marginal. At first sight it appears that teachers did not attach great importance to school leadership either; however, a more in-depth analysis shows the proximity of this category with two strongly represented ones, i.e. School culture and Colleagues / significant others.

The main aim of qualitative data analysis and their interpretation was to gain a deeper insight into the nature of individual categories.

\section{Teacher education}

The second highest frequency of occurrence of statements and the fact that all eight teacher commented on education indicate the perceived significance of both the pre-service and in-service education.

Clearly, in terms of pre-service teacher education, the socio-political changes in the Czech Republic in 1989 affected teachers' perceptions here. The change opened up new opportunities to gain qualifications in the teaching of western languages. Those teachers, who, for various social, political, or personal reasons, entered the universities only after 1989 with prior professional teaching experience, in general took a more positive view of formal pregraduate studies, no matter how demanding it was for them to meet the demands of a professional and a student.

Thus, subjective perceptions of pre-service education as a determinant of professional development were polarized, as illustrated by the following statements.

And I think that there were inspirational people who taught didactics in our studies. My studies really helped me to get those things straight in my headbecause they were linked to theory and because you could get feedback on some of your ideas or lessons or some part of your work and it was no longer so intuitive. (T6 $\left.{ }^{1}\right)$

University was a prerequisite of the career, so it was normal, but I wouldn't say that my studies really confirmed it for me, definitely not, it was more to do with other influences than the faculty itself. (T11)

As regards in-service education, three clusters of opinions were identified:

Firstly, most expert teachers perceived in-service education as a crucial prerequisite for their own professional growth. They were active in searching for the opportunities to learn, and engaged in further education in the roles of learners as well as tutors. Experts perceived further education as an obligation, but also as a pleasure and an impetus for their own betterment as teachers. This corresponds with the results of other studies on expertise; e.g. case studies by Tsui (2003), or with the dynamic view of expertise (Bereiter, Scardamalia, 1993). It is of interest to mention here that even systemic changes imposed by educational policy such as reforms in language education or curricular reforms, however critical general attitude towards them, presented an opportunity to learn for the experts. Similar tendencies of experts are reported e.g. in studies by Huberman (1993a), Hargreaves (2003) and Day et al. (2007).

In the context of social and political development in the Czech Republic, social changes played a special role: foreign language teachers' biographies vividly expressed the pioneering enthusiasm after 1989, when the barriers crashed and they

\footnotetext{
${ }^{1}$ To mark the teachers codes beginning with the letter $\mathrm{T}$ (= teacher) are used. The numbers in the codes are in the range of 1 to 30 , which corresponds to the code established in the first phase of the research, even though they went to the third phase and interviews were conducted only with 8 teachers (T6, T8, T11, T14, T21, T22, T27, T30)
} 
could finally enjoy foreign culture/s, represented e.g. by the presence of native speakers and the activities and support of relevant institutions (Peace Corps, the British Council, the Goethe Institute).

It was amazing, everything that was organized in those first years -I often spent the weekends in Prague, you could meet all those ambassadors, language experts and authors of textbooks there. So I didn't waste any time. And it's not that you're just doing it for yourself, even if it is good for the soul, but you can pass it on. (T21)

Regarding the standard continuous professional development (CPD), teachers appreciated mainly its benefits at the beginning of their careers (cf. Cherubini, 2009), and subsequently their domain-specific orientation, e.g. being acquainted with new trends in language teaching (such as ICT4ELT).

It is symptomatic that in the course of their careers almost all of the expert teachers acted as CPD tutors, leading proficiency oriented and FLT seminars. They explicitly expressed their commitment to passing on and sharing experience with other colleagues, thereby contributing significantly to the emancipation of the profession (cf. Hattie, 2003, 2012).

I try to give a lot back. So, for example, I do some courses for teachers. Recently I've been doing a lot of things on new curricula, because I did some work for the tests and standardization and things like that. I try to be useful not just directly in training, but also in those things which are like an extension. (T27)

Teachers regarded their engagement in CPD as a new stimulus and refreshment.

And for a long time I also ran language courses and I also helped in the preparation of the state language exams. I was doing it partly for myself, because it is very bad to be at a standstill in language, and the fact that I taught very bright young people, educated professionals, meant I always had to be on the alert, so in terms of the language I really got a lot out of it. (T21)

Last but not least, all expert teachers sooner or later in their biographies brought up self-study induced through reflection on their experience (cf. Joyce, Showers, 2002).

When I was looking for a system to monitor how to evaluate whether the kids had completed a task or not, that led me to study books on management, and so I hit upon methods of time management, etc. So I also found a lot of inspiration from that end. (T14)

\section{School culture}

Expert teachers viewed school culture as an amalgam of occupational culture (Lortie, 1975) and institutional culture. Therefore, its influence on their professional development was perceived as substantial, which corresponds to research findings from other cultures (Fullan, Hargreaves, 1992; Kramis, Felber, 2005). School culture in teachers' comments seemed to be crucial for increasing motivation, provision of new initiatives and challenges, as well as strengthening teachers' dedication and sense of professional identity (cf. Pol et al., 2013 for the Czech context).

As regards the influence of school culture on teachers' professional development, both strong and weak cultures (Grimmet, Crehan, 1992: 59-60) were experienced by the experts in various stages of their professional lives. Reminiscences of professional induction (and professional socialization) were particularly explicit.

The first three years were great from a personal viewpoint as well. And the children were different from the city children, which I didn't realize until later, but they were much more open and friendly, even if they didn't always get perfect marks. And there was a really wonderful atmosphere there. Everyone 
helped you out and no-one laughed at you because you were a beginner or tried to trip you up. It was really wonderful. (T11)

I had a class with about 42 children and I was stuck away near the basement because there was no room, and I was practically ignored. At that first place it was kind of... well, I wouldn't say, 'It was great there,' definitely not. (T27)

It is of particular interest, however, that all the teachers characterized the culture of their current workplace as strong, supportive, progressive or even exceptional.

I don't know if my experience is typical for someone in Czech education. This school is doing things a little bit differently, pushing back the boundaries and moving things on, and very often it is close to the edge, looking for a kind of framework - legal and suchlike. And I think that it is why I'm still at this school. I can't really imagine how compatible I'd be with a conservative school. (T6)

They commented upon the quality of cooperation, autonomy, creativity, shared values, and explicit norms of behavior. Correspondence with the results of the above mentioned comparative TALIS study (Scheerens et al., 2010: 32-35), which emphasizes the importance of the school as a learning community, is obvious.

The above qualities of school culture were sometimes linked to the specifics of schools with extended language teaching. These tend to be rather prestigious schools where greater demands are placed on teachers in terms of quality of instruction, curricular work, but also autonomy and creativity. Obviously, such demands contribute to the development of teachers' pedagogical content knowledge (Shulman, 1986). Expert teachers generally perceived these extra demands positively, i.e. as challenging and stimulating.

When it comes to German, our school is a rarity as we teach it from the first grade. So, to convince the parents who send their children to us so that they can learn English from the first year, and then in May I appear among them with my first years, showing them how well their German is coming along, then we are always able to get half a class, sometimes a whole one, that is a great success. (T8)

\section{School leadership}

In the analysis the representation of the category School leadership was rather lean (low frequency, brevity of statements). If mentioned by the experts at all, then they expressed appreciation of the school leadership as a source of support. It is perhaps not surprising given the close relationship with the categories School culture and Colleagues / significant others.

Expert teachers highlighted the principal's role of a colleague and teaching model (collegial and instructional leadership; cf. Marks, Printy, 2003, etc.). In terms of school management, it was not only material conditions, but also encouragement and appreciation of teachers' work as well as promotion of participative decision making and teacher empowerment which they appreciated. The role of the principal as a communicator of shared school vision was regarded as crucial which corresponds with the study by Geijsel et al. (2003) focusing on transformational leadership.

A colleague, an inspiring person, as a principal of my school is actually a guru, with whom I can talk and think about these things. I think that cooperation was and still is very beneficial for me. Just the fact that she is a few steps ahead and thinks about these things from the perspective of a wealth of experience. But on the other hand she has a vision of the future and can see further ahead than either me or most of my younger colleagues. (T6)

It is interesting that none of the expert teachers commented on the school leadership critically, despite the fact that they are undoubtedly capable of taking an analytical and critical view of professional matters. Their biographies highlighted their agency - in case of dissatisfaction they either took on an active role (four of them 
had direct experience with leadership positions at schools), or chose to change the school (cf. Laursen, 2005).

\section{Autonomy}

In the analysis, McGrath's (2000) conceptualization of teacher autonomy was adopted. He worked with two dimensions of the concept: autonomy as self-directed action or development, and autonomy as freedom from control by others.

Firstly, a majority of statements identified in the analysis explicitly linked professional autonomy with specific activities of teachers. Expert teachers gained responsibility for various issues within the school, e.g. designing school curricular documents; Clement and Vandenberghe (2000: 90) use the term ascribed autonomy in this sense. The teachers felt trusted when starting something new (e.g. participating in projects, selecting textbooks, organizing language exams, school theatre, further education courses for teachers both within and outside school), or when solving critical incidents and problems. They made use of these opportunities willing to invest in change and showed courage to alter the established system in an original and innovative manner.

I'm quite proud of the system that we have here. We put a lot of work into it. It's my baby, I look after it and I have a good feeling which I will take with me when I leave, that for the 20 years I've been able to influence things here, in the positive sense of the word. (U27)

And related to that is the great freedom in my work and the opportunity to look for new projects to be involved in and to establish teams for them and that sort of support, that's all a part of it. (T6)

The teachers considered the freedom to experiment and innovate vital for their professional development, even at the cost of considerable personal investments.

And we fought hard when we were trying to push things through. Because we've been teaching English from the first grade for nearly 15 years, which is an awfully long time. So behind that is a lot of work and a lot of experience. (T11)

Existing research studies indicate that the level of teacher autonomy is usually rather low (e.g. Busher, Saran, 1994; Pol et al., 2013). For expert teachers in this study, on the contrary, a high degree of autonomy was characteristic. They clearly tended to take on responsibility, perceived it as natural and automatic. It appears that for them autonomy as freedom from control was interconnected with autonomy as a personal attribute and a self-regulatory competence in. In order to develop, expert teachers deliberately required opportunities to act autonomously, i.e. conditions, but also external support.

\section{Colleagues / significant others}

The category Colleagues / significant others was by far the most frequently represented in the analysis. Furthermore, it proved considerable agreement in expert teachers' subjective perceptions of this determinant. Within the category, four main issues have emerged.

Expert teachers often spoke about the role of professional role models and collegial support in the sense of "great examples" as well as personal role models. This influence was apparent throughout the trajectories of their professional careers.

I think that what you grow up to be is always a question of great examples, and I feel that I was incredibly fortunate with the teachers who led me towards what I'm doing now. (T21)

I also think that I was strongly influenced by my long-time colleague because she is completely different from me and she really motivates me. She's solid and 
her performance is always improving, her work is consistent and she's always aiming to be better, whereas I seem to be up and down - sometimes I'm enthusiastic, sometimes I'm not, and I'll always see the things that I haven't done right. When I see her and how she is always trying to be positive, then I have to say that she has influenced me a great deal. (T27)

In many cases, identified cooperation with colleagues in the staffroom was closely related to the categories of School leadership, School culture and Autonomy. Expert teachers viewed collegial cooperation as a sine qua non for forming a functional team of teachers, introducing innovations, improving the quality in teaching and aiming towards common goals. The experts' statements corresponded with the current conception of professional learning as a socially rooted process in which collegial cooperation plays a fundamental role, with emphasis being placed on the communities of practice as a means of supporting the professional development of individual teachers and the quality of the school as an institution (Kwakman, 2003).

A functional staffroom was perceived as a prerequisite for a teacher to identify with their school, colleagues and school objectives, for their professional commitment. Teacher professionality is thus viewed as dependent on the ethos of professionalism within the school culture (Hoyle, 1975). Expert teachers' subjective perceptions are here in harmony with the view of professionalism as " an ideologically-, attitudinally-, intellectually-, and epistemologically-based stance on the part of an individual, in relation to the practice of the profession to which s/he belongs, and which influences her/his professional practice" (Evans, 2008: 28). To avoid the danger of oversimplification, it is worth stressing that the key issue for expert teachers were not only human relationships, but rather the respect for common objectives and shared professional honor - what Sockett (1993) would call moral professionalism. This applies not only within the school but also for subject communities across the schools - to networks and joint projects.

The spectrum of people there is incredibly broad. So I wouldn't want to pick out one person, but there are several people who you can learn and get new perspectives from. (T6)

With the German teaching you could say that the collegial basis more or less works. We are mainly united by the fact that we're leading the children towards some objective and we all have to be good in order for that to work, so that unites us in a way. (T30)

Last but not least, the analysis revealed that expert foreign language teachers tended to perceive the specifics of their subject subculture quite strongly (cf. Grossman, Stodolosky, 1993). They reported about the relationships between teams of language teachers and other colleagues within the school which emerged as rather tense, sometimes even marked by rivalry. On the other hand, the appreciation of a certain prestige foreign language teams hold in their schools was apparent - it gave these teachers a strong voice (empowerment).

It's true that some of our colleagues might think that we spend too much time on languages, but on the other hand there are a lot of colleagues from other subjects who are aware of the fact that if it wasn't for the languages, there wouldn't be so many children at the school. (T11)

\section{Teacher appraisal / recognition by the community}

Positive appraisal of a teachers' work and recognition of their qualities are factors which were reported as a direct influence their professional satisfaction and motivation (Million, 2004 etc.).

Teachers in this study highly valued especially appreciation of their efforts by members of their own professional community, be it within their own school by their immediate colleagues and school leadership, or outside, by teachers from other 
schools, former teachers, Czech School Inspectorate, universities, or representatives of educational policy. Recognition of their expertise took on various forms, from positions of authority at school to supervision of networks or projects, etc.

Then the revolution came, and because I had taught at this school, which had been a language school, they came and asked me if I would become a deputy head. (T11)

I worked at the Faculty of Education, for me it's a kind of reward. Because these days, two of my students work at my school, now they are colleagues. And so when I see them putting into practice what I drummed into them, what more could a teacher want? (T8)

Acknowledgement by former learners was another valuable psychic reward (Lortie, 1975). As most of expert teachers in this study were active CPD tutors, the term learners applies to a wide range of subjects here - from pupils or students at schools to other members of professional community. Despite the fact that this kind of feedback is often received after a considerable lapse in time, teachers viewed such evaluation as important and encouraging, particularly because in the teaching profession it cannot be taken for granted (Hanushek, 2002).

I've been at this school for 20 years now. So if I meet their parents or if I meet those kids or if they come to the school and they say, 'Miss, I'm now doing such and such a job because of your German classes', or 'Miss, I got a job in a company in England thanks to the fact that I spoke good German' and so on, then you realize that your work has some meaning. (T8)

Then a teacher came to me and she said: 'Do you remember me? I was at your course and it was excellent.' So that always makes you feel good, when you remember how many teachers were in those CPD courses. (T11)

The effects recognition of their work has on expert teachers are obvious: it raises their self-esteem and self-confidence, points out their expert skills and inspires them in their future work, empowers them and strengthens their commitment (cf. Million, 2004).

\section{Parents (and community around school)}

The cultural level of influence on expertise development includes the community around school, usually putting accent on the roles of parents. Therefore a low occurrence of statements identified in this category may seem rather surprising. If mentioned at all, the prevailing perception of collaboration with parents was positive.

The children come here and the parents send them here because languages are taught well here, because the children really learn something. For the majority, education is something which is valued, and that influences the atmosphere at the school because the parents motivate the children. Not in all cases, of course - we do have some children now who couldn't care less, but it is a fact that compared to other schools there is a higher percentage of parents who get their children to study and who support them a lot. (T11)

A balanced or positive perception of collaboration with parents is a particularly interesting result because contemporary research in the world and in the Czech Republic provides evidence to worsening of relations between parents and schools (cf. e.g. Scherff, 2008). A closer look at the reasons for satisfaction seems to support the conclusions of the study by Rabušicová et al. (2003: 114) that "the climate of a particular school related to attitudes and opinions is a far better predictor of satisfaction with cooperation - both from the school and from the parents - than a list of activities carried out by the school for the parents". 


\section{Educational policy}

Data interpretation within this category needs to take into account current Czech context: a controversial conception and implementation of a curricular reform, current unstable political situation, and contemporary social climate. Expert teachers' statements can be interpreted as qualified criticism emerging from a deep knowledge of the situation.

Negative perception of educational policy prevailed, as reflected in critical statements, in which expert teachers strongly emphasized a missing vision. Teachers pointed out the society-wide orientation on performance/results and the effects of neoliberal trends in education, managerism, which together with changes in society's value system (focus on profit) results in extreme pressures on schools and teachers. Similar trends have been detected worldwide, e.g. in England (Day, Gu, 2010), Canada and the USA (Hargreaves, 2003; Darling-Hammond et al., 2005), Australia (Sachs, 2000).

Everything will concentrate a lot on output and profit, then there will be less and less time for the children, and frankly the results in those schools will not be much better. When that reform began I didn't change anything. Yes, I wrote out what I had taught in the columns, but no real change took place. So I think that perhaps it isn't just about education, it's more about today's society. But I am an optimist and I think it is possible that it's already beginning to change a little, that people are already realizing that we can't go on like this. (T22)

Interestingly, though expert teachers' attitude to social change and educational reform was analytical and critical, it completely lacked (negative) emotions, although existing research identified emotions as a frequent concomitant of reforms (in Europe and Australia in particular; Sutton, Wheatly, 2003). Some expert teachers, in contrast to their usual active engagement, do not invest in reform activities - unless they perceive them as meaningful. Generally, they are capable to filter faddish trends drawing on their experience, knowledge of the system and, last but not least, theoretical knowledge - their approach to these trends is informed and efficient. This is visible in a domain-specific area (e.g. politically correct trends in ELT), as well as in domain general issues (degradation of university education as a result of its massification).

The other thing is that when $60 \%$ of the year group is accepted into university, then there can't be the same standard, and you can't be surprised at who teaches our children. (T30)

These findings indicate that, particularly in relation to an externally imposed (topdown) educational change, expert teachers display a considerable degree of agency (Eteläpeltö et al., 2013). If they perceive the change meaningful, they evince adaptive expertise (Hatano, Inagaki, 1986). In an unstable context, in which it is not possible to apply quick, effective, routine solutions to standard situations, they are able to perform a corresponding degree of innovation and restructuring of competencies on the basis of contextual needs. Thus, apart from professional knowledge at the level of a deep conceptual understanding, adaptive experts prove that they are capable of taking an active role in professional discourse.

\section{Economic conditions}

Questions of prestige, social recognition of importance and quality of teaching is often measured against the level of financial reward, which is why the economic conditions were classified as an independent category within the cultural level of influence. The analysis, however, revealed that for expert teachers in recollection of their professional lives economic conditional were a marginal issue. The prevalence of intrinsic, psychic rewards (see the category Teacher appraisal / recognition by the community) over extrinsic rewards has been repeatedly documented by research 
related to educational reforms, e.g. in the USA already in 1980 s by Rosenholtz and Smylie (1984). If statements concerning financial matters occurred at all (see Tab. 1), then it was in relation to the prestige of the profession.

Sometimes you have the feeling that you are doing your best and that it is pointless or that it isn't valued, because society is set up in such a way that a proper vocation just isn't rated. And then maybe you're short of money too and you say to yourself, Why? I work so hard, I do such useful work, so how is it that I don't get as much money as some lawyer? (T22)

\section{Conclusion}

Contextual factors have been recognized as determinants of teachers' professional development since Waller's (1932) early classic in the field of sociology of education which provided a pioneering study of school as a social institution. In the Western world research into external or objective determinants of quality (in) teaching has gained in importance with the accelerating pace of educational reforms since 1980 s and brought a number of significant findings. Yet we could see reasons to undertake this exploration.

Firstly, we have not come across a study that would link teacher expertise with context, in other words, investigate the perceptions of expert teachers. Experts in teaching as well as in other domains are exceptional individuals. Therefore we suggest, it is vital to look at their subjective perceptions of objective determinants rather than on the objective reality - how they perceive educational reality and deal with it is what we need to uncover if we want to learn more about expertise development and maintenance.

Secondly, talking about context necessarily entails its culture specific aspects, be it a broader social, political and economic system, educational policy and schooling in its historical determinedness or the culture of the workplace. Teacher expertise itself is a culturally rooted phenomenon as Tsui (2005: 170-171) noted expressing at the same time doubts "whether it is at all possible or even meaningful to establish criteria which could be applied across cultures". A confrontation of findings across cultures, therefore, may be informative for distinguishing between culture specific and generic aspects of expertise development.

The study focused on objective determinants of expertise development in teachers of foreign languages in the Czech Republic which may be perceived as representative of a relatively large block of post-communist countries. The analysis showed that these cultural specifics were reflected by the teachers at the level of the broader social context, namely in connection with the political change in 1989 and the political 'fall of the wall', and on the level of a specific professional subculture.

Considering the effect sizes of the selected determinants inferred from the saturation of particular categories, three categories emerged as the dominant determinants of teachers' professional growth: Teacher education, School culture and Colleagues / significant others.

It follows that the analysis pinpointed the institutional level of influence, i.e. the teachers' immediate environment, to be crucial. A key role was played by the human factor, by both the individual influences (professional role models, support provided by a colleague, etc.) and the influence of the professional community. A closer look reveals that the important factors were not collaborative activities, but rather a shared value system and attitudes, shared vision and mission of the school, commitment, etc. By contrast, the cultural level of influence was much less represented, though the teachers demonstrated a high level of awareness and an analytical, critical approach especially in the area of educational policy. 
The category Teacher education encompasses all kinds of professional learning opportunities. Search for information and a constant need for new stimuli proved to be typical at all stages of teachers' professional development. They purposefully sought out, selected and utilized opportunities for professional improvement on the basis of reflection on their experience and critical analysis of contextual variables and modified their own practice accordingly. This is considered to be a core feature of adaptive expertise and a prerequisite maintaining a high level of professional performance (Hatano, Inagaki, 1986).

Rather surprisingly, expert teachers' discourse on external infuences on their professional lives was mostly balanced, constructive and devoid of negative emotions. It would be worth further investigation whether they perceived the observed objective determinants as basically positive influences, which enabled or significantly supported their professional growth, or whether their expertise, experience and job satisfaction helped them filter negative emotions. Whichever may prove correct, in this respect our conclusions differ from the results of studies of professional lives of teachers across the age groups and quality of performance spectrum (e.g. Huberman, 1993a; Day et al., 2007; Hargreaves, 2003), in which environmental influences were quite often perceived negatively, as tending to hinder professional growth.

Work context is multidimensional and varied. In spite of the limitations of the study arising from its scope as well as its conceptual and methodological design, it is possible to formulate the conclusions in both the above areas of interest. As regards cultural differences, the study did not pinpoint any significant conceptual specifics the system of categories based on theory and research conducted in other cultures worked fine. However, as the study was conceived as deductive, further culture specific factors exclusive for the culture under investigation may have remained hidden.

Considerable differences, however, were detected in how expert teachers compared to (experienced) non-experts acted in response to these objective determinants. They did not accept the role of 'passive objects' of the impact of external influences. On the contrary, they displayed a high level of agency (Eteläpeltö et al., 2013) in taking the actions, which have contributed and continue to contribute to the co-creation of teachers' environment - especially within their closest context, at the institutional level. Sachs (2000) related such practice to the activist identity, which is manifested by and in the conviction of the necessity to mobilize oneself as well as other teachers in the interests of pupils, and which places emphasis on social ideals and values, and on transcending the narrow instrumentalism of contemporary reforms.

\section{Bibliograpic references}

BALL, S. J. 1981. Beachside comprehensive. Cambridge: Cambridge University Press. ISBN 978-0-521-29878-0

BALL, S. - LACEY, A. 1984. Subject disciplines as the opportunity for group action: a measured critique of subject sub-cultures. In HARGREAVES, A. - WOODS, P. (Eds.). Classrooms and staffrooms. Milton Keynes, Open University Press. ISBN 9780335105830

BEREITER, C. - SCARDAMALIA, M. 1993. Surpassing ourselves: an inquiry into the nature and implications of expertise. Chicago: OpenCor. ISBN 978-0812692051

BERLINER, D. 1986. In pursuit of the expert pedagogue. Educational Researcher, vol. 15 , no.7, pp. 5-13. ISSN 0013-189X

BOSHUIZEN, H. P. A. - BROMME, R. - GRUBER, H. (Eds.). 2004. Professional learning: Gaps and transitions on the way from novice to expert. Dordrecht: Kluwer Academic Publishers.

BRANSFORD, J. D. - BROWN, A. L. - COCKING, R. R. (Eds.). 1999. How people learn: brain, mind, experience, and school. Washington: National Academy Press.

105 
BROPHY, J. - GOOD, T. 1986. Teacher behavior and student achievement. In M. Wittrock (Ed.), Third handbook of research on teaching (pp. 328-375). New York: Macmillan.

BUSHER, H. - SARAN, R. 1994. Towards a Model of School Leadership. Educational Management \& Administration, 22(1), 5-13.

CHI, M. T. H. 2011. Theoretical perspectives, methodological approaches, and trends in the study of expertise. In Y. Li - G. Kaiser (Eds.), Expertise in mathematics instruction (pp. 17-40). New York: Springer.

CHERUBINI, L. 2009 Reconciling the tensions of new teachers' socialisation into school culture: A review of the research. Issues in Educational Research, 19(2), 8399.

CLARK, C. M. - PETERSON, P. L. 1986. Teacher Thought Processes. In M. C. Wittrock

(Ed.), Handbook of Research on Teaching (pp. 255-296). New York: Macmillan.

CLEMENT, M. - VANDENBERGHE, R. 2000. Teachers's professional development: a solitary or collegial (ad)venture? Teaching and Teacher Education, 16(1), 81-101.

DAY, CH. - GU, Q. 2010. The new lives of teachers. London: Routledge.

DAY, CH. - SAMMONS, P. - STOBART, G. - KINGTON, A. - QUING, G. 2007.

Teachers matter: connecting work, lives and effectiveness. Oxford: McGraw Hill.

DARLING-HAMMOND, L. - RICHARDSON, N. 2009. Research Review / Teacher

Learning: What Matters? Retrieved from <http://www.mimathandscience. org/downloads/math_professional_development/how_teachers_learn_20110908_

165813_22.pdf>

DEAL, T.E. - PETERSON, K.D. 1998. How leaders influence the culture of schools.

Educational Leadership, 56(1), 28-30.

ERICSSON, K. A. 2006. An Introduction to Cambridge handbook of expertise and expert performance: its development, organization, and content. In K. A. Ericsson, N. Charness, P. J. Feltovich, \& R. R. Hoffman (Eds), The Cambridge handbook of expertise and expert performance (pp. 3-19). New York: CUP.

ERICSSON, K.A. - CHARNESS, N. - FELTOVICH, P.J. - HOFFMAN, R.R. (Eds.) 2006. The Cambridge handbook of expertise and expert performance. New York: CUP.

ETELÄPELTÖ, A. - VÄHÄSANTANEN, K. - HÖKKÄ, P. - PALONIEMI, S. 2013. What is agency? Conceptualizing professional agency at work. Educational Research Review, 10(December), 45-65.

EVANS, L. 2008. Professionalism, professionality and the development of education professionals. British Journal of Educational Studies, 56(1), 20-38.

FULLAN, M. 2007. The new meaning of educational change (4th ed.). New York: Teachers College Press.

FULlAN, M. - HARGREAVES, A. (Eds.). 1992. Teacher development and educational change. London: Falmer, pp. 1-9.

GEIJSEL, F. - SLEEGERS, P. - LEITHWOOD, K., - JANTZI, D. 2003. Transformational leadership effects on teachers' commitment and effort toward school reform. Journal of Educational Administration, 41, 229-256.

GLASER, R. - CHI, M. T. 1988. Overview. In M. T. Chi - R. Glaser - M. J. Farr (Eds.), The nature of expertise (pp. xv-xxviii). Hillsdale: Erlbaum.

GRIMMET, P. P. - CREHAN, E. P. 1992. The nature of colegiality in teacher development: The case of clinical supervison. In M. Fullan - A. Hargreaves (Eds.), Teacher development and educational change (pp. 56-85). Washington: The Falmer Press.

GROSSMAN, P. L. - STODOLSKY, S. S. 1995. Content as context: the role of school subjects in secondary school teaching. Educational Researcher, 24(8), 5-11. 
HANUSHEK, E. A. 2002. Publicly provided education. In A. J. Auerbach - M. Feldstein (Eds.), Handbook of Public Economics (pp. 2045-2141). Oxford: Elsevier Science Ltd.

HARGREAVES, A. 2000. Four Ages of Professionalism and Professional Learning. Teachers and Teaching: History and Practice, 6(2), 151-182.

HARGREAVES, A. 2003. Teaching in the knowledge society: Education in the age of insecurity. London: Open University Press.

HATANO, G. - INAGAKI, K. 1986. Two Courses of Expertise. In H. Stevenson - H. Azuma - K. Hakuta (Eds.), Child development and education in japan (pp. 262-272). New York: Freeman.

HATTIE, J. A. C. 2003. Teachers make a difference: What is the research evidence? Retrieved from < http:/www.decd.sa.gov.au/limestonecoast/fi les/pages/new\%20page/ PLC/teachers_make_a_difference.pdf $>$

HATTIE, J. A. C. 2012. Visible learning for teachers: Maximizing impact on learning. Oxon: Routledge.

HOYLE, E. 1975. Professionality, professionalism and control in teaching. In V. Houghton et al. (Eds.), Management in education: the management of organisations and individuals (pp. 314-320). London: Ward Lock Educational in association with Open University Press.

HUBERMAN, M. 1993a. The Lives of Teachers. London: Cassell.

HUBERMAN, M. 1993B. The model of the independent artisan in teachers' professional relations. In J. W. Little - M. W. McLaughlin (Eds.), Teachers' work: Individuals, colleagues, and contexts (pp. 11-50). New York: Teachers College Press. JOYCE, B. - SHOWERS, B. 2002. Student achievement through staff development (3rd ed.). New York/London: Longman.

KELCHTERMANS, G. - VANDENBERGHE, R. 1996. Becoming political. A dimension in teachers' professional development. A micropolitical analysis of teachers' professional biographies. Retrieved from $<\mathrm{http}: / \mathrm{fi}$ les.eric.ed.gov/fulltext/ED395921.pdf>

KRAMIS, J. - FELBER, F. 2005. Orientierungsrahmen Schulqualität für Schulevaluation in Kanton Luzern. Luzern: FSL LU.

KWAKMAN, C. H. E. 2003. Factors affecting teachers' participation in professional learning activities. Teacher and Teacher Education, 19, 149-170.

LARSEN-FREEMAN, D. - FREEMAN, D. 2008. Language moves: The place of "foreign" languages in classroom teaching and learning. Retrieved from $<\mathrm{http}: / /$ rre.sagepub.com/content/32/1/147.full $>$

LAZAR, I. (Ed.). 2003. Incorporating intercultural communicative competence in language teacher education. Strasbourg: Council of Europe Publishing.

LIEBERMAN, A. - MILLER, L. 2000. Teaching and teacher development: A new synthesis for a new century. In R.S. Brandt (Ed.), Education in a new era (pp. 47-66). Alexandria, VA: Association for Supervision and Curriculum Development.

LINDLOF, T. R. - TAYLOR, B. C. 2002. Qualitative communication research methods (2nd ed.). Thousand Oaks, CA: Sage.

LITTLE, J. W. - MCLAUGHLIN, M. W. 1993. Teachers' work: Individuals, colleagues, and contexts. New York: Teachers College Press.

LORTIE, D. 1975. Schoolteacher: a sociological study. Chicago: University of Chicago Press.

MARKS, H. M. - PRINTY, S. M. 2003. Principal leadership and school performance: An integration of transformational and instructional leadership. Educational Administration Quarterly, 39(3), 370-397.

MCADAMS, D. P. 2007. The Life Story Interview. Retrieved from $<$ http://www.sesp. northwestern.edu/docs/ LifeStoryInterview.pdf> 
MCGRATH, I. 2000. Teacher autonomy. In B. Sinclair - I. McGrath - T. Lamb (Eds.), Learner autonomy, teacher autonomy: future directions (pp. 100-110). London: Longman.

MILLER, R. L. 2000. Researching life stories and family histories. London/Thousand Oaks: SAGE.

MILLION, J. 2004. Honor your teachers. National Association of Elementary School Principals. Retrieved from <http://www.nbpts.org/ContentLoad.do?contentld=1145>

OJERMARK, A. 2006. Rapporteur's Notes Biographical Research (Salam Fall)

Retrieved from <http://www.chronicpoverty.org/uploads/publication_files/1.1\%20

Rapporteur\%20report\%20-\%20Biographical\%20research.pdf $>$

PARIZEK, V. 1994. Obecná pedagogika. [General pedagogy] Praha: UK.

POL, M. - HLOUSKOVA, L. - LAZAROVA, B. - NOVOTNY, P. - SEDLACEK, M. 2013. Kdyz se skoly uci. [When the schools are learning] Brno: MU.

POLLARD, A. 1982. A model of classroom coping strategies. British Journal of Sociology of Education, 3(1), 19-37.

RABUSICOVA, M. - TRNKOVA, K. - SEDOVA, K. - CIHACEK, V. 2003. O skolach, $\mathrm{v}$ nichz jsou rodice i reditelr spokojeni se vzajemnou spolupraci. [On schools where both parents and teachers are satisfied with mutual collaboration]. Studia Paedagogica, Brno: MU.

RICHARDSON, V. - PLACIER, P. 2001. Teacher change. In V. Richardson (Ed.), Handbook of research on teaching (pp. 905-947). Washington: AERA.

ROSENHOLTZ, S.J. - SMYLIE, M.A. 1984. Teacher compensation and career ladders. Elementary School Journal, 85, 149-16.

SACHS, J. 2000. The Activist Profession. Journal of Educational Change, 1(1) 77-95. SEIDEL, T. - SHAVELSON, R. J. 2007. Teaching Effectiveness Research in the Past Decade: The Role of Theory and Research Design in Disentangling Meta-Analysis Results. Review of Educational Research, 77(4), 454-499.

SCHEERENS, J. (Ed). 2010. Teachers' Professional Development. Europe in international comparison. Luxembourg: Office for Official Publications of the European Union. Retrieved from <http://ec.europa.eu/education/schooleducation/development_en.htm>

SCHERFF, L. 2008. Disavowed: The stories of two novice teachers. Teaching and Teacher Education, 24(5), 1317-1332.

SHULMAN, L. S. 1986. Paradigms and research programs in the study of teaching: a contemporary perspective. In M. C. Wittrock (Ed.), Handbook of Research on Teaching (pp. 3-36). New York: Macmillan.

SISKIN, L. 1994. Realms of knowledge: Academic departments in secondary schools. London/New York: The Falmer Press.

SOCKETT, H. 1993. The moral base for teacher professionalism. New York/London: Teachers College: Columbia University.

STERNBERG, R. J. - HORVATH, J. A. 1995. A Prototype View of Expert Teaching. Educational Researcher, 24(6), 9-17.

SUTTON, R. E. - WHEATLEY, K. F. 2003. Teachers' Emotions and Teaching: A Review of the Literature and Directions for Future Research. Educational Psychology, 15(4), 327-358.

TERHART, E. 2005. Pädagogische Qualität, Professionalisierung und Lehrerarbeit. Vierteljahrschrift für wissenschaftliche Pädagogik, 81, 79-97.

TOMA, J. D. 2005. Approaching Rigor in Applied Qualitative Research. In C. F. Conrad - R. C. Serlin (Eds.), The SAGE handbook for research in education. (pp. 405-424). London: SAGE.

TSUI, A. B. M. 2003. Understanding expertise in teaching. Cambridge: CUP. 
TSUI, A. B. M. 2005. Expertise in teaching: Perspectives and issues. In K. Johnson (Ed.), Expertise in second language teaching and learning (pp. 167-189). New York: Palgrave Macmillan.

WALLER, W.W. 1932. The Sociology of Teaching. New York: Wiley.

WIPPERFÜRTH, M. 2009. Welche Kompetenzstandards brauchen professionelle Fremdsprachenlehrer und -lehrerinnen? Forum Sprache, 1(2), 6-26.

The research was supported by the grant P407/11/0234 Expert Teacher: the nature of expertise and determinants of professional development (in foreign language teaching perspective) provided by the Czech Science Foundation.

Words: 9896

Characters: 65716 (36, 51 standard pages)

Mgr. Klára Uličná, Ph.D.

Charles University

M.D.Rettigove,

116 36, Praha,

Czech Republic

klara.ulicna@pedf.cuni.cz

Assoc. Prof. PhDr. Michaela Píšová, M.A., Ph.D.

Masaryk University

Porici 7

60300 Brno

Czech Republic

pisova.mich@gmail.com

Assoc. Prof. Světlana Hanušová, Ph.D.

Masaryk University

Porici 7

60300 Brno

Czech Republic

hanusova@ped.muni.cz

Prof. PhDr. Věra Janíková, Ph.D.

Masaryk University

Porici 7

60300 Brno

Czech Republic

janikova@ped.muni.cz

Mgr. Petr Najvar, Ph.D.

Masaryk University

Porici 7

60300 Brno

Czech Republic

najvar@ped.muni.cz 